\title{
ECOLOGICAL AND SOCIAL «RISK FACTORS» FOR STUDENTS' HEALTHY LIFESTYLE PROMOTION
}

\section{(C) 2018}

Shvechikhina Yulia Vladimirovna, postgraduate student of Ecology, Botany and Nature Protection Department Kavelenova Lyudmila Mikhailovna, doctor of biological sciences, professor, head of Ecology, Botany and Nature Protection Department

Rytov Gleb Lvovich, candidate of pedagogical sciences, associate professor, head of Biological Department Samara National Research University (Samara, Russian Federation)

Abstract. The most important condition for the sustainable development of socio-ecological and economic systems at all levels, from regional to national, is undoubtedly a balanced socio-demographic development. It is connected with the presence of sufficiently numerous social groups of a professionally competent, physically and morally healthy population that also serves as the basis for the national security of the country. The number of students in the Samara Region at the level of more than 100 thousand people provides good opportunities for qualified professionals' training, whose activities are not limited to the space of the Samara Region. In addition to acquiring professional knowledge, skills and general and special competencies development, young people studying in higher education must also acquire a deep and conscious motivation to lead a healthy lifestyle. In this paper, we present a part of the comprehensive research that we are already carrying out, related to the ecology-population basics of student health status promotion. An important moment in this respect is, according to WHO, the fight against obesity, and one of the relatively accessible indicators is the body mass index (BMI). For model groups of Samara University students the distribution according to the body mass index shows a prevalence of the normal level of the indicator (from 20 to 24) - for young men and the indicator 20 (the lower limit of the norm) for girls. This is a good «starting point» for motivating students to lead a healthy lifestyle in the future.

Keywords: social and demographic challenges; Samara Region; student youth; healthy lifestyle promotion; environmental factors; social factors; psychological factors; health status; ecological and population basis; motivation for healthy lifestyle; body mass index; distribution pattern.

\section{ЗООПЛАНКТОН ПОЙМЕННЫХ ОЗЁР РЕКИ КЕРЖЕНЕЦ (КЕРЖЕНСКИЙ ЗАПОВЕДНИК, НИЖЕГОРОДСКАЯ ОБЛАСТЬ)}

(C) 2018

Шурганова Галина Васильевна, доктор биологических наук, профессор кафедры экологии Жихарев Вячеслав Сергеевич, магистрант кафедры экологии

Кудрин Иван Александрович, кандидат биологических наук, ассистент кафедры экологии Национальный исследовательский Нижегородский государственный университет им. Н.И. Лобачевского (2. Нижний Новгород, Российская Федераиия)

Кривдина Татьяна Васильевна, научный сотрудник Морева Ольга Алексеевна, научный сотрудник

Нижегородское отделение Государственного научно-исследовательского института озёрного и речного рыбного хозяйства им. Л.С. Берга (г. Нижний Новгород, Российская Федераиия)

Аннотация. В работе представлены результаты исследований зоопланктона в июне, июле и сентябре 2017 года в восьми пойменных водоёмах среднего течения реки Керженец, расположенных на территории Керженского биосферного заповедника. Исследованные водные объекты являются мелководными озёрами со слабокислой ( $\mathrm{pH} 5,40-6,23)$ и маломинерализованной $(46,90-68,40$ мг/л) водой с повышенными значениями цветности (202,00-1048,20 град.) и содержания взвешенных веществ (4,40-22,90 мг/л). В результате проведённых гидробиологических исследований было идентифицировано 106 видов зоопланктона. По зоогеографической характеристике фауна зоопланктона пойменных водоёмов является типичной для водоёмов Европейской части России, за исключением двух видов-вселенцев: североамериканской коловратки Kellicottia bostoniensis (Rousselet, 1908) и каспийского ветвистоусого рачка южного происхождения Diaphanosoma orghidani (Negrea, 1982). Кроме того, в ряде озёр был обнаружен арктический реликтовый рачок Holopedium gibberum (Zaddach, 1855), который внесён в Красную книгу Нижегородской области. Коловратка Kellicottia bostoniensis в ряде пойменных водоёмов являлась доминирующим видом и имела высокую численность. Рачок Diaphanosoma orghidani был обнаружен только в двух водоёмах, его численность была невысокой, и он не играл значительной роли в сообществах зоопланктона этих озёр. Новые находки арктического реликтового вида Holopedium gibberum (Zaddach, 1855) позволяют рекомендовать внесение некоторых пойменных водоёмов в Красную книгу Нижегородской области как местообитания этого редкого вида. Анализ избыточности (RDA) позволил выявить четыре фактора, статистически значимо объясняющих видовую структуру сообществ зоопланктона в ряде пойменных водоёмов: температура воды, водородный показатель (pH), содержание растворённого кислорода и количество взвешенных веществ.

Ключевые слова: зоопланктон; видовое богатство; водоёмы; река Керженец; биосферный заповедник Керженский; ординация; виды-вселенцы; пойменные озёра; структура сообществ; сообщества гидробионтов; численность; биомасса; факторы среды; Kellicottia bostoniensis; Diaphanosoma orghidani; Holopedium gibberum; Нижегородская область. 


\section{Введение}

Изучение сообществ зоопланктона важно для понимания особенностей функционирования гидробиоценозов в различных природных комплексах. Большое видовое богатство планктонных сообществ вносит важнейший вклад в биоразнообразие водных ценозов. В современной экологии водоёмов и водотоков основной интерес уделяется наиболее значимым в хозяйственном отношении объектам - крупным озёрам, рекам, водохранилищам. В то же время гидробиологический режим небольших озёр остаётся менее изученным, что связано, прежде всего, с их многочисленностью и разнообразием характеристик, что в особенности затрудняет проведение постоянных исследований [1, с. $122 ; 2$, с. 217]. Пойменные озёра являются неотъемлемым элементом ландшафта. Неправильное управление природными ресурсами приводит к деградации и исчезновению этих экосистем, известных высоким уровнем биоразнообразия и экологической ценности [3]. Кроме того, проведение исследований зоопланктона водных объектов ООПТ имеет большое значение, поскольку территория водосбора испытывает минимальное антропогенное воздействие, что позволяет изучать сообщества в естественных фоновых условиях [4]. Такие исследования расширяют представление о биоразнообразии и биоресурсном потенциале не только отдельно взятых регионов области, но и целых природных зон страны [5].

Пойменные озёра играют существенную роль в системе реки. Они выступают в роли геохимического барьера (уменьшают приток питательных веществ и загрязняющих веществ в реку) [6, р. 298], обеспечивают укрытие для животных после наводнений на реках, представляют собой среду обитания для гидробионтов [1, с. 122]. Гидробиологические исследования пойменных водоёмов Керженского биосферного заповедника носят эпизодический характер.

Цель работы - описать зоопланктон некоторых пойменных водоёмов, расположенных на территории Керженского биосферного заповедника и выявить абиотические факторы, определяющие его развитие с применением современных методов математического анализа.

\section{Материалы и методы исследования}

Гидробиологические исследования проводились в июне, июле и сентябре 2017 года на мелководных озёрах, расположенных на территории Керженского биосферного заповедника в долине среднего течения реки Керженец. Керженец - река Нижегородского Заволжья, левый приток р. Волги. Её протяжённость составляет 290 км, площадь водосборного бассейна -

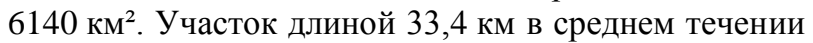
входит в государственный природный биосферный заповедник «Керженский» [7, с. 45].

Исследованные водоёмы (оз. Сиротинное, оз. Гришино, оз. Красный Яр, оз. Чёрный Яр, оз. Драничное, оз. Новая старица, оз. Чернозерское-1, оз. Чернозерское-2) - это озёра, имеющие небольшую площадь и глубину, не более 4 м. Водоёмы находятся на разном отдалении от русла реки (от нескольких метров до 100 м), а оз. Новая старица соединено с рекой протокой (рис. 1).

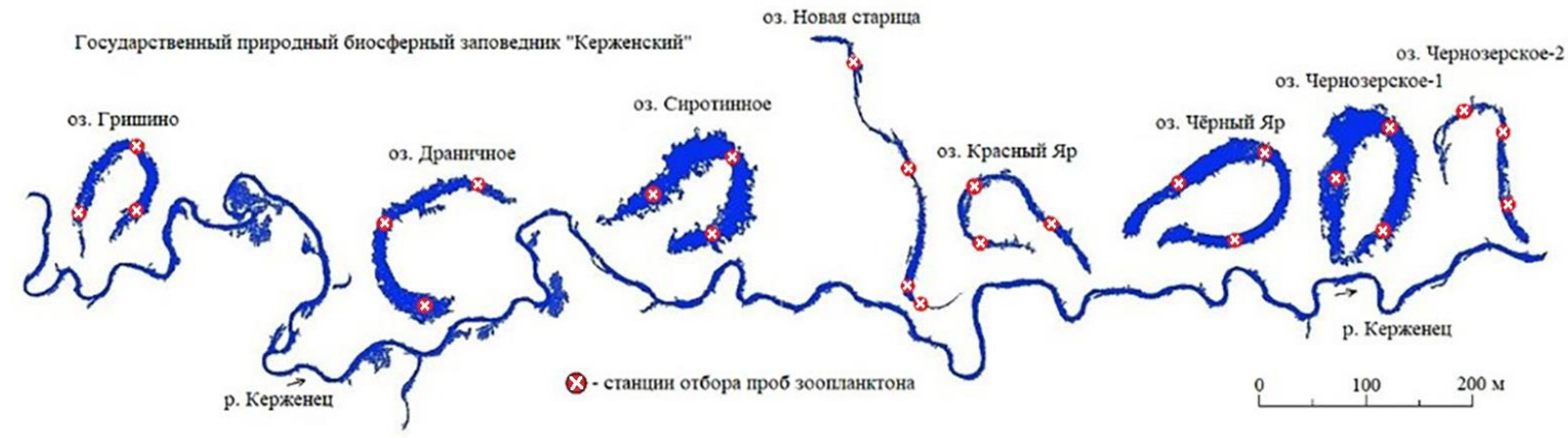

Рисунок 1 - Картосхема станций отбора проб зоопланктона на акватории пойменных водоёмов среднего течения реки Керженец в 2017 году

Пробы зоопланктона на участках с глубиной более 2 м собирались путём тотальных обловов от дна до поверхности количественной сетью Джеди (нейлоновое сито с ячеей 70 мкм), на мелководье - процеживанием 100 л воды через сеть Апштейна (нейлоновое сито с ячеей 70 мкм) и фиксировались 4\% раствором формалина. Обработка материала проводилась по стандартным методикам, используемым в практике гидробиологических исследований [8]. Виды зоопланктона устанавливались с использованием определителей и руководств [9]. При определении вида Kellicottia bostoniensis (Rousselet, 1908) пользовались работами J. de Paggi [10] и В.И. Лазаревой, С.М. Ждановой [11]. Для оценки зависимости видовой структуры зоопланктоценозов от факторов среды использовали ординационный метод анализа избыточности (redundancy analysis, RDA) [12-14]. Bce расчеты проводились в среде R [15].

\section{Результаты и их обсуждение}

В течение вегетационного сезона (июнь, июль, сентябрь) 2017 г. на акватории исследованных водоёмов в общей сложности было идентифицировано 106 видов планктонных организмов, из них 57 видов (54\%) относилось к коловраткам (Rotifera), 35 видов (33\%) - к ветвистоусым ракообразным (Cladocera), 14 видов (13\%) - к веслоногим ракообразным (Сореpoda) [16]. По зоогеографической характеристике фауна зоопланктона пойменных водоёмов среднего течения реки Керженец является типичной для водоёмов Европейской части России, за исключением двух видов-вселенцев: североамериканской коловратки Kellicottia bostoniensis (Rousselet, 1908) и каспийского ветвистоусого рачка южного происхождения Diaphanosoma orghidani (Negrea, 1982) [16].

Большинство видов всех водоёмов являлись представителями II трофического уровня, ведущими 
плавающий образ жизни. Среди них преобладали первичные фильтраторы и вертикаторы. Кроме того, были обнаружены типичные виды болотной фауны или виды, тяготеющие к кислым водам [4].

\section{Количественные характеристики}

Количественное развитие зоопланктона в течение трёх месяцев наблюдения существенно изменялось (табл. 1). Максимальные значения численности зоопланктона зарегистрированы в июне в оз. Чёрный Яр

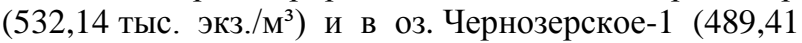
тыс. экз./ $\mathrm{M}^{3}$ ) (табл. 1). Минимальные - в оз. Новая старица в июне $\left(10,76\right.$ тыс. экз./м $\left.{ }^{3}\right)$ и июле $(4,82$ тыс. экз./Mํ). Биомасса зоопланктона исследованных во- доёмов определялась их видовым составом. В течение сезона в большинстве изученных водоёмов наблюдалась смена рачкового планктона на коловраточный, за исключением оз. Новая старица, в котором в течение всего сезона доминировал крупный $\alpha$ мезосапробный рачок Daphnia pulex (Leydig, 1860), причём его численность к концу сезона (сентябрь) значительно увеличилась. Максимальные значения биомассы зоопланктона зарегистрированы в июне в оз. Чёрный Яр $-4,5$ г $/ \mathrm{m}^{3}$ и сентябре в оз. Новая старица $-4,03$ г/м². Минимальные значения биомассы зарегистрированы в июле в оз. Красный Яр $\left(0,09 \Gamma / \mathrm{M}^{3}\right)$.

таблица 1 - Основные количественные характеристики развития зоопланктона в течение вегетационного сезона 2017 года на акватории исследованных водоёмов

\begin{tabular}{|c|c|c|c|c|c|c|c|c|c|}
\hline \multirow{2}{*}{ Водный объект } & \multicolumn{3}{|c|}{ июнь } & \multicolumn{3}{|c|}{ июль } & \multicolumn{3}{|c|}{ сентябрь } \\
\hline & $N$, тыс. экз./ $\mathrm{M}^{3}$ & $B, \Gamma / \mathrm{M}^{3}$ & $S$ & $N$, тыс. экз./ $\mathrm{M}^{3}$ & $B, \mathrm{M \Gamma} / \mathrm{M}^{3}$ & $S$ & $N$, тыс. экз./ $\mathrm{M}^{3}$ & $B, \mathrm{M} \Gamma / \mathrm{M}^{3}$ & $S$ \\
\hline Оз. Сиротинное & 158,73 & 3,93 & 23 & 47,28 & 0,32 & 23 & 35,10 & 0,13 & 13 \\
\hline Оз. Гришино & 224,22 & 0,34 & 12 & 103,61 & 0,79 & 42 & 161,90 & 0,36 & 11 \\
\hline Оз. Красный Яр & 96,71 & 0,37 & 14 & 7,69 & 0,09 & 16 & 22,70 & 0,59 & 20 \\
\hline Оз. Чёрный Яр & 532,14 & 4,50 & 20 & 79,36 & 1,55 & 25 & 236,00 & 0,44 & 14 \\
\hline Оз. Драничное & 41,66 & 0,98 & 24 & 209,51 & 1,68 & 24 & 282,20 & 0,11 & 11 \\
\hline Оз. Новая старица & 10,76 & 0,13 & 18 & 4,82 & 0,56 & 31 & 70,35 & 4,03 & 6 \\
\hline Оз. Чернозерское-1 & 489,41 & 2,87 & 24 & 66,89 & 0,83 & 22 & 39,35 & 1,01 & 11 \\
\hline Оз. Чернозерское-2 & 371,77 & 0,32 & 22 & 53,39 & 2,44 & 27 & 46,20 & 2,31 & 13 \\
\hline
\end{tabular}

Примечание. $N$ - численность зоопланктона; $B$ - биомасса зоопланктона; $S$ - видовое богатство зоопланктона.

\section{Чужеродные и редкие виды зоопланктона}

В зоопланктоне исследованных водоёмов в течение вегетационного сезона 2017 года было идентифицировано два вида-вселенца: североамериканская коловратка Kellicottia bostoniensis (Rousselet, 1908) и южный каспийский рачок Diaphanosoma orghidani (Negrea, 1982). Кроме того, в ряде озёр был обнаружен арктический реликтовый ветвистоусый рачок Holopedium gibberum (Zaddach, 1855), который внесён в Красную книгу Нижегородской области как редкий и находящийся на границе ареала вид.

Реликтовый вид Holopedium gibberum (Zaddach, 1855) был обнаружен в пяти пойменных водоёмах (табл. 2) только в июне и июле. Максимальное значение численности этого вида было зарегистрировано в июле в оз. Чёрный Яр - 21,93 тыс. экз./ м $^{3}$ (27,63\% от общей численности зоопланктона). Кроме того, арктический вид также входил в число доминирующих видов в оз. Чернозерское- 1 (25,46\% от общей численности зоопланктона). Водоемы, в которых был обнаружен рачок Holopedium gibberum (Zaddach, 1855), являются олиготрофными со слабоминерализованными (46,9-68,40 мг/л), слабокислыми (5,83-6,20 у.е.) водами с высокой цветностью (210,86-574,80 град.), а также относительно невысоким содержанием растворенного кислорода $(3,1-$ 4,2 мг/л). Поскольку некоторые озера Низменного Заволжья имеют ряд параметров, характерных для северных водоемов тайги и тундры, где этот вид широко распространен (низкие значения минерализации и $\mathrm{pH}$, а также высокие значения цветности), они становятся благоприятными для обитания (и даже массового развития) в них арктического реликтового вида Holopedium gibberum (Zaddach, 1855) [17, c. 299].

таблица 2 - Основные количественные характеристики развития арктического реликтового рачка Ноlоpedium gibberum в течение вегетационного сезона 2017 года на акватории исследованных водоёмов

\begin{tabular}{|c|c|c|c|c|c|c|}
\hline \multirow{2}{*}{ Водный объект } & \multicolumn{2}{|c|}{ июнь } & \multicolumn{2}{|c|}{ июль } & \multicolumn{2}{|c|}{ сентябрь } \\
\hline & $N$, тыс. экз./ $\mathrm{M}^{3}$ & $\%$ от $N_{t o t}$ & $N$, тыс. экз./ $\mathrm{M}^{3}$ & $\%$ от $N_{t o t}$ & $N$, тыс. экз./ $\mathrm{M}^{3}$ & $\%$ от $N_{t o t}$ \\
\hline Оз. Сиротинное & - & - & 1,70 & 3,59 & - & - \\
\hline Оз. Красный Яр & 0,20 & 0,20 & - & - & - & - \\
\hline Оз. Чёрный Яр & 9,41 & 1,77 & 21,93 & 27,63 & - & - \\
\hline Оз. Чернозерское-1 & 16,47 & 3,37 & 17,03 & 25,46 & - & - \\
\hline Оз. Чернозерское-2 & 0,04 & 0,01 & - & - & - & - \\
\hline
\end{tabular}

Примечание. $N_{\text {tot }}$ - общая численность зоопланктона.

Количественные характеристики чужеродных видов существенно различались. Коловратка Kellicottia bostoniensis (Rousselet, 1908), обнаруженная в течение вегетационного сезона во всех исследованных водоёмах, имела наиболее высокую численность в июне и сентябре. В июне в оз. Чернозёрское- 2 её численность составляла 65,88 тыс. экз./ $\mathrm{M}^{3}(17,72 \%$ от общей численности зоопланктона), в сентябре в 140 оз. Драничное - 251,00 тыс. экз./м³ (89,05\% от общей численности зоопланктона) (табл. 3).

Каспийский рачок Diaphanosoma orghidani (Negrea, 1982) был обнаружен только в оз. Чёрный Яр и оз. Чернозерское-1 только в июле. Его численность была низкой и не превышала 0,25 тыс. экз./Mㄹ, а доля от общей численности зоопланктона $0,32 \%$. 
Таблица 3 - Основные количественные характеристики развития североамериканской коловратки Кеllicottia bostoniensis (Rousselet, 1908) в течение вегетационного сезона 2017 года на акватории исследованных водоёмов

\begin{tabular}{|c|c|c|c|c|c|c|}
\hline \multirow{2}{*}{ Водный объект } & \multicolumn{2}{|l|}{ июнь } & \multicolumn{2}{|l|}{ июль } & \multicolumn{2}{|c|}{ сентябрь } \\
\hline & $N$, тыс. экз. $/ \mathrm{M}^{3}$ & $\%$ от $N_{t o t}$ & $N$, тыс. экз./ $/ \mathrm{M}^{3}$ & $\%$ от $N_{t o t}$ & $N$, тыс. экз. $/ \mathrm{M}^{3}$ & $\%$ от $N_{t o t}$ \\
\hline Оз. Сиротинное & 0,43 & 0,27 & 0,006 & 0,01 & 3,00 & 8,55 \\
\hline Оз. Гришино & 0,03 & 0,01 & 0,41 & 0,40 & 104,00 & 64,20 \\
\hline Оз. Красный Яр & - & - & - & - & 0,20 & 0,88 \\
\hline Оз. Чёрный Яр & 11,76 & 2,21 & - & - & 4,00 & 1,69 \\
\hline Оз. Драничное & 0,26 & 0,63 & 8,05 & 3,84 & 251,00 & 89,05 \\
\hline Оз. Новая старица & 1,45 & 13,45 & - & - & 1,00 & 1,42 \\
\hline Оз. Чернозерское-1 & 16,47 & 3,37 & - & - & 15,50 & 39,39 \\
\hline Оз. Чернозерское-2 & 65,88 & 17,72 & 0,28 & 0,52 & 0,35 & 0,76 \\
\hline
\end{tabular}

Примечание. $N_{\text {tot }}$ - общая численность зоопланктона.

\section{Ординация данных}

Гидрохимический анализ воды исследованных пойменных водоёмов проводился в лаборатории Нижегородского отделения ГосНИОРХ им. Л.С. Берга. Для оценки зависимости видовой структуры сообществ зоопланктона исследованных водоёмов от факторов среды были построены модели на основе анализа избыточности (RDA) с учётом факторов среды, представленных в табл. 4. Статистический анализ вспомогательных моделей, которые были по- строены для каждого отдельного фактора, показал, что значение $\mathrm{p}<0,05$ имели: температура воды, водородный показатель, содержание растворённого кислорода и количество взвешенных веществ (табл. 5). Наибольший вклад в объяснение изменчивости видовой структуры вносил водородный показатель $(17,77 \%)$, меньшую долю объясняли факторы температуры, количества взвешенных веществ и растворенного кислорода $(13,47-13,88 \%)$.

Таблица 4 - Гидрохимическая характеристика исследованных пойменных водоёмов (по данным 2017 года)

\begin{tabular}{|l|c|c|c|c|c|c|c|c|}
\hline \multirow{2}{*}{ Показатель } & \multicolumn{7}{c|}{ Водные объекты } \\
\cline { 2 - 10 } & 1 & 2 & 3 & 4 & 5 & 6 & 7 & 8 \\
\hline pH & 6,23 & 5,80 & 5,83 & 5,40 & 5,86 & 6,00 & 6,06 & 6,20 \\
\hline Взвешенные в-ва, мг/л & 7,36 & 8,83 & 4,40 & 22,9 & 12,4 & 11,06 & 6,13 & 6,23 \\
\hline Цветность, град & 203,56 & 202,00 & 210,86 & 1048,20 & 480,00 & 574,80 & 310,46 & 321,03 \\
\hline Fе, мг/л & 0,40 & 0,61 & 0,39 & 3,28 & 1,28 & 1,52 & 0,79 & 0,74 \\
\hline Жесткость, мг/л & 0,54 & 0,50 & 0,39 & 0,73 & 0,67 & 0,47 & 0,40 & 0,54 \\
\hline Минерализация, мг/л & 62,77 & 51,23 & 46,90 & 57,80 & 68,40 & 46,90 & 51,40 & 67,23 \\
\hline Электропроводность, мкС/см & 56,00 & 42,30 & 37,00 & 40,30 & 61,30 & 39,00 & 39,00 & 62,70 \\
\hline Аммонийный азот, мг/л & 0,76 & 0,53 & 0,47 & 1,21 & 0,76 & 0,97 & 0,78 & 0,54 \\
\hline Нитриты, мг/л & 0,04 & 0,03 & 0,03 & 0,09 & 0,05 & 0,07 & 0,04 & 0,02 \\
\hline Нитраты, мг/л & 0,90 & 0,79 & 0,35 & 1,55 & 0,89 & 0,97 & 0,85 & 0,44 \\
\hline Минеральный азот, мг/л & 1,69 & 1,35 & 0,86 & 2,84 & 1,70 & 2,01 & 1,69 & 1,01 \\
\hline Минеральный фосфор, мг/л & 0,11 & 0,12 & 0,10 & 0,29 & 0,14 & 0,20 & 0,14 & 0,17 \\
\hline О $_{2}$ мг/л & 4,95 & 4,44 & 3,59 & 1,65 & 1,33 & 3,43 & 4,28 & 1,34 \\
\hline Температура, ${ }^{\circ}$ С & 22,83 & 21,49 & 22,48 & 20,78 & 18,33 & 24,63 & 22,37 & 20,17 \\
\hline Перманганатная ок-ть, мгО $2 / л$ & 26,53 & 16,10 & 16,93 & 62,93 & 33,33 & 44,80 & 32,4 & 12,70 \\
\hline
\end{tabular}

Примечание. 1 - оз. Гришино; 2 - оз. Драничное; 3 - оз. Сиротинное; 4 - оз. Новая старица; 5 оз. Красный Яр; 6 - оз. Чёрный Яр; 7 - оз. Чернозерское-1; 8 - оз. Чернозерское-2.

Таблица 5 - Статистический анализ данных анализа избыточности (RDA) для каждого из исследованных факторов среды

\begin{tabular}{|l|c|c|c|}
\hline \multicolumn{1}{|c|}{ Фактор } & $\begin{array}{c}\text { Скорректированная доля } \\
\text { объясняемой дисперсии, \% }\end{array}$ & $\begin{array}{c}\text { Значение } \\
\text { критерия Фишера, } F\end{array}$ & $p$ значение \\
\hline Температура (Тетр) & 13,47 & 2,09 & $\mathbf{0 , 0 2}$ \\
\hline Водородный показатель $(\mathrm{pH})$ & 17,77 & 2,51 & $\mathbf{0 , 0 1}$ \\
\hline Растворённый кислород $\left(\mathrm{O}_{2}\right)$ & 13,88 & 2,13 & $\mathbf{0 , 0 4}$ \\
\hline Взвешенные в-ва (S_sol) & 13,56 & 2,10 & $\mathbf{0 , 0 2}$ \\
\hline
\end{tabular}

Примечание. ${ }^{*}-\mathrm{p}<0,05$

Полная модель с использованием всех четырёх факторов значимо объясняла $29,73 \%$ от общей дисперсии видовой структуры зоопланктона. На ординационной диаграмме (рис. 2) вдоль горизонтальной оси ординации, значимо объясняющей $13,36 \%$ от общей дисперсии видовой структуры, выделяются 2 группы озёр. Изменения вдоль второй вертикальной оси ординации не были значимыми $(\mathrm{p}=0,44)$. 


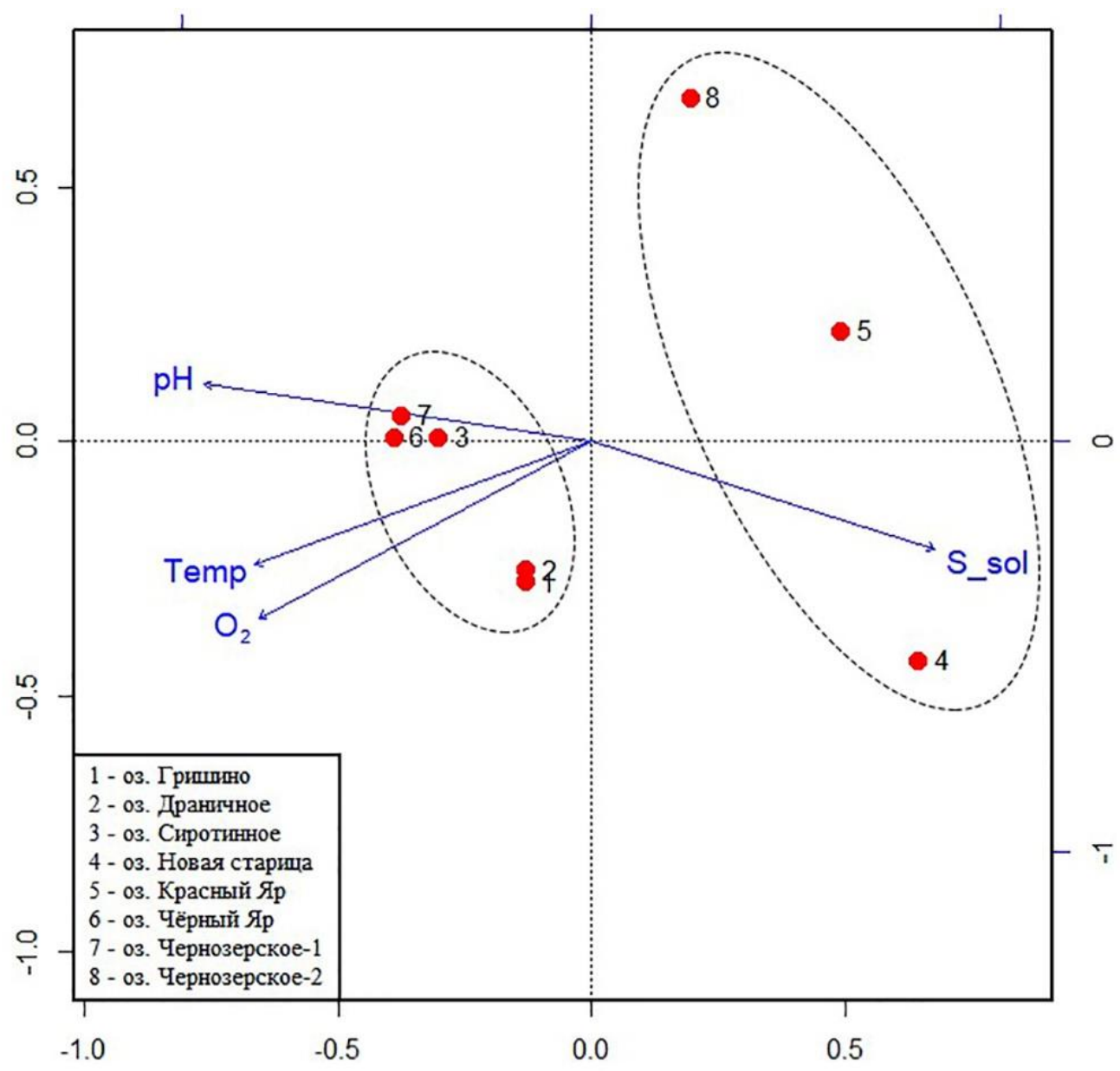

Рисунок 2 - Результаты ординации видовой структуры зоопланктона изученных озёр и их связь с факторами среды в июле 2017 года ( $p H$ - водородный показатель; Тетр - температура воды; $\mathrm{O}_{2}$ - содержание растворённого кислорода в воде; $S$ _sol- количество взвешенных веществ в воде)

К первой группе водоёмов относятся близкие по видовой структуре сообщества зоопланктона озёр Гришино, Драничное и несколько более обособленные от них сообщества озёр Сиротинное, Чёрный Яр и Чернозерское-1. Кроме близости видовой структуры зоопланктоценозов, воды озёр первой группы характеризуются повышенными значениями коррелирующих между собой $\mathrm{pH}$, температуры и растворенного кислорода. Озёра второй группы - озёра Новая старица, Красный Яр, Чернозерское- - характеризовались повышенным количеством взвешенного вещества.

\section{Выводы}

В результате гидробиологических исследований ряда пойменных водоёмов среднего течения реки Керженец было идентифицировано 106 видов зоопланктона. Зоопланктон пойменных водоёмов, расположенных на территории Керженского биосферного заповедника, имеет достаточно богатый таксономический состав.

Большинство идентифицированных видов 3оопланктона исследованных водных объектов имеют широкое всесветное распространение - космополиты [18]. Исключение составляют чужеродная для палеарктики североамериканская коловратка Kellicottia bostoniensis (Rousselet, 1908). Кроме того, в зоопланктоне исследованных озёр был обнаружен каспийский южный рачок Diaphanosoma orghidani (Negrea, 1982). Эти виды ранее не были указаны в списках видов беспозвоночных организмов, обитающих в водоёмах Керженского биосферного заповедника.
Коловратка Kellicottia bostoniensis (Rousselet, 1908) в ряде пойменных водоёмов являлась доминирующим видом (до $89,05 \%$ от общей численности зоопланктона) и имела высокую численность (до 251,00 тыс. экз./ $\mathrm{M}^{3}$ ). Рачок Diaphanosoma orghidani (Negrea, 1982) был обнаружен только в двух водоёмах, его численность была низкой, и он не играл значительной роли в сообществах зоопланктона этих водоёмов. Однако находки чужеродных видов зоопланктона на территории Керженского биосферного заповедника свидетельствуют о продолжающемся активном расселении этих видов по территории Нижегородской области. Kellicottia bostoniensis (Rousselet, 1908) на сегодняшний день обитает уже в 46 водоёмах и водотоках Нижегородской области. Эти виды обладают широкой экологической пластичностью [19, p. 401]. Для контроля за количественным развитием видоввселенцев и изучения их экологических особенностей необходимо проведение постоянных мониторинговых исследований.

Впервые отмеченный для ряда пойменных озёр представитель арктический фауны ветвистоусых ракообразных Holopedium gibberum (Zaddach, 1855) в оз. Чёрный Яр и оз. Чернозерское-1 являлся доминирующим видом и играл значительную роль в видовой структуре сообществ зоопланктона. Результаты исследований позволяют рекомендовать внесение изученных водоёмов в Красную книгу Нижегородской области в качестве местообитаний Holopedium gibberum (Zaddach, 1855). 
Анализ избыточности (RDA) позволил выявить четыре фактора, статистически значимо определяющих развитие зоопланктона в ряде пойменных водоёмов: температура воды, водородный показатель, содержание растворённого кислорода и количество взвешенных веществ. Наибольший вклад в объяснение изменчивости видовой структуры вносил водородный показатель $(17,77 \%)$, что связано с кислым характером вод исследованных водоёмов, которые питаются водами реки Керженец (в период паводков) и болотными водами с прилегающих территорий. Меньшую долю объясняли факторы температуры, количества взвешенных веществ и растворенного кислорода $(13,47-13,88 \%)$.

\section{Список литературы:}

1. Афонина Е.Ю., Итигилова М.Ц. Зоопланктон малых пойменных озёр бассейна реки Иля // Учёные записки ЗабГУ. 2017. Т. 12, № 1. С. 121-128.

2. Крылов А.В. Межгодовые изменения летнего зоопланктона пойменных озёр р. Хопёр // Поволжский экологический журнал. 2014. № 2. С. 216-226.

3. Лобуничева Е.В. Зоопланктон малых водоёмов разных ландшафтов Вологодской области: автореф. дис. ... канд. биол. наук: 03.00.16, 03.00.18. Борок, 2009. 19 c.

4. Ильин М.Ю. Состав и структура сообществ зоопланктона водных объектов особо охраняемых природных территорий (на примере Нижегородской области): дис. ... канд. биол. наук. Нижний Новгород, 2016. $227 \mathrm{c}$.

5. Павлов Д.С., Крылов А.В., Дгебуадзе Ю.Ю. Гидробиологические и ихтиологические исследования на базе заповедников, их направления и перспективы // Заповедники России и устойчивое развитие: матер. юбилейной конф., посв. 75-летию Центральнолесного государственного биосферного заповедника (21-25 августа 2007 г.). Труды ЦЛГЗ. вып. 5. C. $48-59$.

6. Lake P.S., Bond N.R. Australian futures: freshwater ecosystems and human water usage // Futures. 2007. Vol. 39. P. 288-305.

7. Фридман Б.И., Кораблёва О.В. Геология и рельеф Керженского заповедника // Природные условия Керженского заповедника и некоторые аспекты охраны природы Нижегородской области. Труды ГПЗ «Керженский». Т. 1. Нижний Новгород, 2001. C. 7-70.

8. Методические рекомендации по сбору и обработке материалов при гидробиологических исследованиях на пресноводных водоемах. Зоопланктон и его продукция / сост. А.А. Салазкин и др. Л.: ГосНИОРХ, 1984. 33 с.

9. Определитель зоопланктона и зообентоса пресных вод Европейской России. Т. І. Зоопланктон / под ред. В.Р. Алексеева и С.Я. Цалолихина. М.: Товарищество научных изданий КМК, 2010. 495 с.

10. De Paggi J. New Data on the Distribution of $K$. bostoniensis (Rousselet, 1908) (Rotifera: Monogononta: Brachionidae): Its Presence in Argentina // Zool. Anzeiger. 2002. Vol. 241. P. 363-368.

11. Лазарева В.И., Жданова С.М. Американская коловратка Kellicottia bostoniensis (Rousselet, 1908) (Rotifera: Brachionidae) в водохранилищах бассейна Верхней Волги // Биология внутренних вод. 2014. № 3. С. 64-78.

12. Шитиков В.К., Зинченко Т.Д., Розенберг Г.С. Макроэкология речных сообществ: концепции, методы, модели. Тольятти: Кассандра, 2011. 255 с.

13. Шитиков В.К., Розенберг Г.С. Рандомизация и бутстреп: статистический анализ в биологии и экологии с использованием R. Тольятти: Кассандра, 2013. $314 \mathrm{c}$.

14. Legendre P., Legendre L. Numerical ecology. Oxford: Elsevier, 2012. 990 p.

15. The R Project for Statistical Computing [El. resource] // The R Project for Statistical Computing.

16. Шурганова Г.В., Гаврилко Д.Е., Жихарев В.С., Кудрин И.А., Ильин М.Ю., Золотарева Т.В., Голубева Д.О. Экодиагностика водоемов питьевого водоснабжения крупного мегаполиса (на примере г. Нижнего Новгорода) // Известия Самарского научного центра Российской академии наук. 2016. Т. 18, № 52. C. $387-392$.

17. Подшивалина В.Н. Особенности биологии и распространения Holopedium gibberum Zaddach (Crustacea, Cladocera) на территории зоны южной тайги Низменного Заволжья // Поволжский экологический журнал. 2012. № 3. С. 295-301.

18. Segers H. Annotated checklist of the rotifers (Phylum Rotifera), with notes on nomenclature, taxonomy and distribution. Auckland: Magnolia Press, 2007. $104 \mathrm{p}$.

19. Shurganova G.V., Gavrilko D.E., Il'in M.Iu., Kudrin I.A., Makeev I.S., Zolotareva T.V., Zhikharev V.S., Golubeva D.O., Gorkov A.S. Distribution of Rotifer Kellicottia bostoniensis (Rousselet, 1908) (Rotifera: Brachionidae) in Water Bodies and Watercourses of Nizhny Novgorod Oblast // Russian Journal of Biological Invasions. 2017. Vol. 8, № 4. P. 393-402.

\section{ZOOPLANKTON OF FLOODPLAIN LAKES OF THE RIVER KERZHENETS (KERZHINSKI NATURE RESERVE, NIZHNY NOVGOROD REGION)}

(C) 2018

Shurganova Galina Vasilievna, doctor of biological sciences, professor of Ecology Department Zhikharev Vyacheslav Sergeevich, master student of Ecology Department

Kudrin Ivan Aleksandrovich, candidate of biological sciences, assistant of Ecology Department National Research Lobachevsky State University of Nizhny Novgorod (Nizhny Novgorod, Russian Federation)

Krivdina Tatyana Vasilievna, researcher

Moreva Olga Alekseevna, researcher

Nizhny Novgorod branch Berg State Research Institute on Lake and River Fisheries

(Nizhny Novgorod, Russian Federation)

Abstract. The paper presents the results of zooplankton research in June, July and September 2017 in eight floodplain lakes of the middle reaches of the Kerzhenets River located in the Kerzhinski Nature Reserve. The studied wa- 
ter bodies are shallow lakes with weakly acidic $\mathrm{pH}(5,40-6,23)$ and low mineralized water $(46,90-68,40 \mathrm{mg} / \mathrm{l})$, with increased chromaticity (202,00-1048,20 deg.) and content of suspended substances (4,40-22,90 mg/l). As a result of a carried out hydrobiological research, 106 species of zooplankton were identified. According to the zoogeographical characteristics, the zooplankton fauna of floodplain water bodies is typical for the European part of Russia, with the exception of two invasive species: the North American rotifers Kellicottia bostoniensis (Rousselet, 1908) and the Caspian branching diocese of southern origin Diaphanosoma orghidani (Negrea, 1982). In addition, in a number of lakes, the Arctic relict crustacean Holopedium gibberum (Zaddach, 1855) was found. The crustacean is listed in the Red Data Book of the Nizhny Novgorod Region. Alien rotifers in a number of floodplain reservoirs were the dominant species and had a high abundance. The Caspian southern crustacean was found only in two reservoirs, its number was not high, and it did not play a significant role in the zooplankton communities of these reservoirs. New findings of the Arctic relict species Holopedium gibberum (Zaddach, 1855) make it possible to recommend the introduction of a number of floodplain reservoirs into the Red Book of the Nizhni Novgorod Region as habitats of this rare species. Redundancy analysis (RDA) has revealed four factors that significant related with development of zooplankton in a number of floodplains, such as water temperature, hydrogen index, dissolved oxygen content and suspended solids.

Keywords: zooplankton; species richness; water bodies; Kerzhenets River; Kerzhensky Biosphere Reserve; ordination; invasive species; floodplain lakes; community structure; hydrobiont communities; abundance; biomass; environmental factors; Kellicottia bostoniensis; Diaphanosoma orghidani; Holopedium gibberum; Nizhny Novgorod Region. 